DOI 10.7764/ijanr.v48i3.2328

\title{
Management of Water Resources in Agriculture in Chile and its Challenges
}

\author{
Guillermo Donoso \\ Pontificia Universidad Católica de Chile, Facultad de Agronomía e Ingeniería Forestal, Department of \\ Agricultural Economics and Water Law and Management Center. Santiago, Chile.
}

\begin{abstract}
G. Donoso. 2021. Management of Water Resources in Agriculture in Chile and its Challenges. Int. J. Agric. Nat. Resour. 171-185. Water is a strategic resource for agricultural development, particularly in the arid and semiarid regions of central and northern Chile. Currently, irrigated surfaces contribute between 60 and $65 \%$ of the country's agricultural GDP. Associated with Chile's economic growth, total consumptive water use has increased, which, together with population growth, urbanization, water contamination and pollution, has led to important water stress situations that are triggering a greater number of conflicts and social, economic, and environmental vulnerability. The above phenomena will be exacerbated by climate change. At present, surface water deficit covering irrigation demands exists in the central and northern regions. This deficit is projected to increase as a result of climate change, which would increase the challenges for satisfying agricultural water requirements. The objective of this article is to integrally review the key aspects of Chilean water and agricultural water management policies, considering their interphases, providing the reader with a general overview of the main features of this model, an evaluation of its effectiveness and the main challenges agricultural water management faces. Resolving the challenges of the future requires a thorough reconsideration of water management policies and institutions and how water is managed in the agricultural sector in the broader context of overall water resource management in Chile.
\end{abstract}

Keywords: Agricultural water management, Water governance, Water management, Water policy, Water rights markets, Chile

\section{Introduction}

Water has always been a strategic resource for economic development, particularly in the arid and semiarid regions of northern Chile. Irrigation systems were developed by native people even before the Spanish colonial period, which allowed

Received May 05, 2021. Accepted Oct 25, 2021 Corresponding author: gdonosoh@uc.cl for the development of a prosperous agricultural economy in temperate, semiarid and even arid regions (Sandoval Jeria, 2003).

Currently, irrigation is important in the Chilean agricultural sector and, therefore, in its contribution to the development of the country. The production of irrigated surfaces contributes between 60 and $65 \%$ of the country's agricultural GDP (Martin $\&$ Saavedra, 2018). On the other hand, irrigated 
agriculture contributes more than $80 \%$ of the country's agricultural exports. It should be noted that the agricultural sector is the main economic sector in terms of the use of water resources, consuming $82 \%$ of the total consumptive water extraction at the national level (DGA, 2016).

In recent years, water stress in Chile has increased due to various factors. These include population growth, rapid urbanization, water pollution, increased demand for resources, and increased variability in supply. Currently, the country is classified in a state of "high" to "extremely high" water stress (World Resources Institute, 2021), varying throughout the country. All the regions north of Maule face extremely high water stress, while the Nuble region faces high stress, and the Biobio and Araucanía regions face medium high stress.

As Figure 1 shows, the current balance of available surface water between the Atacama and Biobío regions, the regions that concentrate $88 \%$ of the country's irrigated surface, indicates a deficit of surface water to cover the irrigation demands between the Atacama and Metropolitan regions ${ }^{1}$ (ODEPA 2017) (Figure 1).

Additionally, Chile's hydrological regulation capacity is limited (Banco Mundial, 2011). The water storage capacity in Chile for irrigation reaches a total of $4,460 \mathrm{hm}^{3}$ (million $\mathrm{m}^{3}$ ), concentrated in the northern macroregion ${ }^{2}$ at $74 \%$ (Figure 2). Water reservoir investments, such as large reservoirs, dams and infiltration systems and aquifer recharge, are planned for the next decade (DGA, 2016).

The deficit in available surface water has been partially covered by the extraction of groundwater. The number of groundwater rights granted increased by 4,350\% between 2001 and 2017, while surface water rights grew by $207 \%$ during the same period (Donoso et al., 2020). Today, the importance of groundwater as a water source is particularly evident in the northern and central

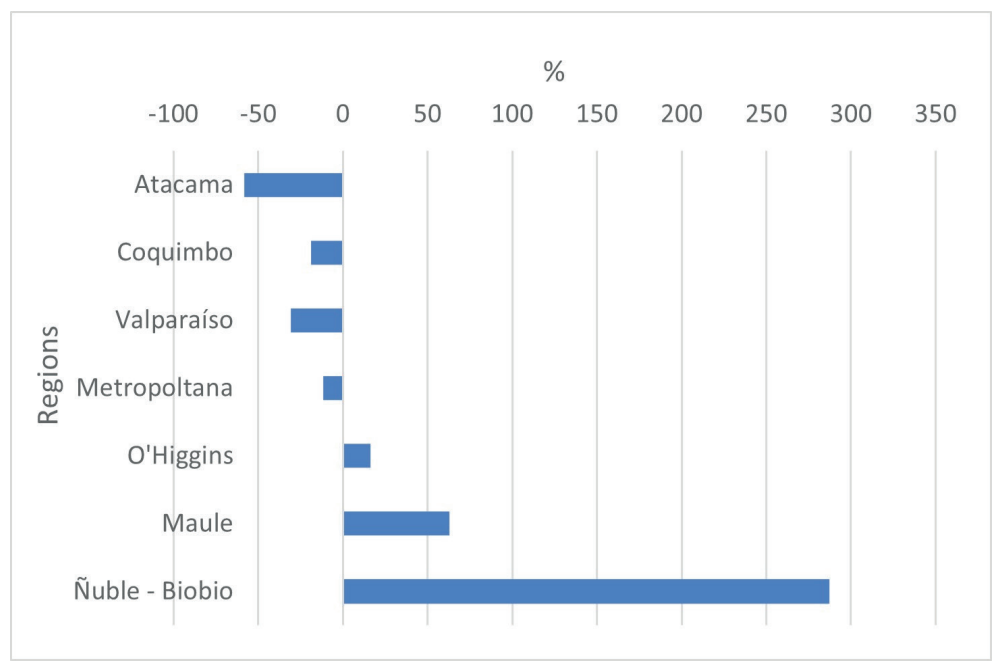

Figure 1. Surface water deficit or surplus for irrigation.

\footnotetext{
${ }^{1}$ The water balance percentages are calculated as agricultural water balance with respect to surface water available for agriculture.

${ }^{2}$ From a hydrometeorological point of view, Chile can be divided into 4 macroregions (McPhee, 2018): northern (15 to $\left.25^{\circ} \mathrm{S}\right)$, central $\left(25\right.$ to $\left.40^{\circ} \mathrm{S}\right)$, southern $\left(40\right.$ to $\left.45^{\circ} \mathrm{S}\right)$, and austral ( 45 to $\left.56^{\circ} \mathrm{S}\right)$.
} 


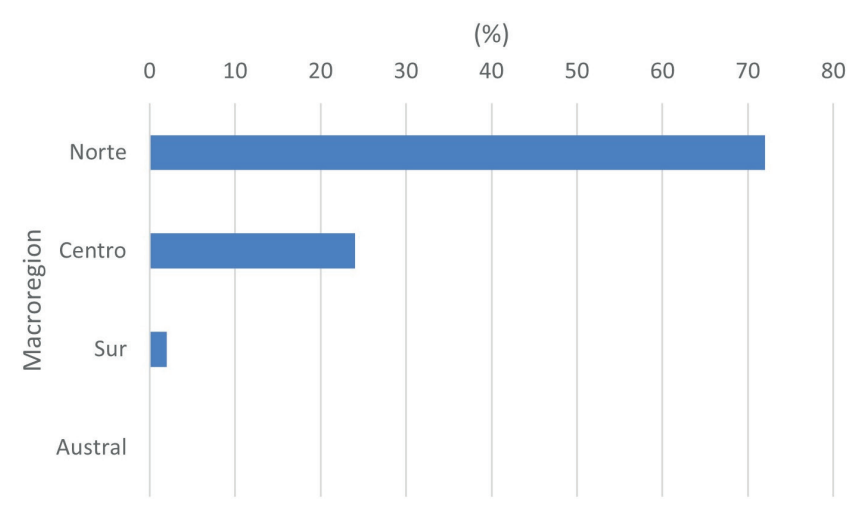

Figure 2. Water accumulation capacity for irrigation by Macroregion.

macroregions. The rapid development of the use of groundwater has generated decreases in water levels (McPhee, 2018).

The streamflow deficit is projected to increase as a result of climate change (CC), with significant impacts on agricultural GDP (ODEPA, 2010). Additionally, it is anticipated that the reduction in snow accumulation in the Andes will cause hydrological deregulation, increasing winter runoff and reducing its availability when required for irrigation (ODEPA, 2017). In other words, it will increase the deficit of surface water for irrigation; hence, the importance of groundwater as a source of water for irrigation will grow. Thus, in a CC scenario, based on the projections of the Hadley Center Coupled Model global climate model, version 3 (HadCM3) under a "severe" scenario (A2), a reduction in agricultural GDP of approximately $16 \%, 12 \%$ and $5 \%$ is estimated for the north, center, and south macroregions, respectively (ODEPA, 2010, 2017).

Several authors have studied water policy in Chile from a governance and legal perspective, as well as water rights history (e.g., Bauer, 1997, 2010, 2012; Hearne and Donoso, 2005, 2014; Budds, 2009, 2018; Hurlbert \& Diaz, 2013; Donoso, 2018; Prieto et al., 2020). Another extensive strand of literature has focused on the Chilean water markets (Bauer, 2004; Bjornlund \& McKay, 2002; Budds
2004; Hadjigeorgalis, 2009; Hearne, 2007, 2018; Grafton et al., 2011; Donoso 2015). Fewer studies have analyzed agricultural water management policy and governance in Chile (e.g., PalermViqueira, 2010; ODEPA, 2012, 2017; Martin \& Saavedra, 2018). This partial treatment of water policy and management issues has led to an incomplete and piecemeal analysis of the various challenges at stake. Taking this into account, the objective of this article is to integrally review the key aspects of Chilean water and agricultural water management policies, considering their interphases, providing the reader with a general overview of the main features of this model, an evaluation of its effectiveness and the main challenges agricultural water management faces. Resolving the challenges of the future requires a thorough reconsideration of water management policies and institutions and how water is managed in the agricultural sector in the broader context of overall water resource management in Chile.

In the following sections, irrigation in Chile is characterized. The legal and institutional framework for water management in Chile and agriculture is then described, followed by an analysis of the effectiveness of this framework. The paper ends with a discussion of the lessons learned and the challenges for water management in agriculture. 


\section{Irrigation in Chile}

Chile's irrigated area has increased in recent years, currently reaching approximately $1,100,000$ irrigated hectares $(27 \%$ and $42 \%$ of the agricultural and cultivated areas, respectively). Figure 3 shows the irrigated area with respect to the agricultural area by region (based on ODEPA, 2012, 2019). A total of $68.4 \%$ of these are concentrated in the central macroregion, followed by the southern macroregion with $20.9 \%$ and the northern macroregion, representing $9.4 \%$ of the national irrigated surface.

The main irrigation system used in Chile is gravitational, representing $72 \%$ of the irrigated area (Martin \& Saavedra, 2018). It is followed in importance by microirrigation with $23 \%$ and, finally, sprinkler irrigation systems, which represent $5 \%$ of the total irrigated surface. The main gravitational system used in Chile is flooding, with $58 \%$ of the total; this is the gravitational irrigation system with the lowest irrigation efficiency $(30 \%)^{3}$.
The average irrigation efficiency increased by 17\% between 1997 and 2007, from an average of $48.6 \%$ in 1997 to $56.9 \%$ in 2007 (ODEPA, 2017; Martin \& Saavedra, 2018). This is explained by a decrease in the area with $17.8 \%$ gravitational irrigation and an increase of $85.1 \%$ and $298.2 \%$ in the areas with sprinkler irrigation and microirrigation, respectively. The greatest increases are observed in the northern and central macroregions (INE, 1997, 2007) (Figure 4). The highest irrigation efficiency, $65 \%$, is found in the northern macroregion, which corresponds to the most arid area. Irrigation efficiencies systematically decrease toward the south of the country, which is explained by the reduction in the relative scarcity of water.

As in other countries, increases in irrigation efficiency have not generated savings or reductions in water consumption by farmers since they have increased their irrigated area. This effect is known as Jevon's paradox or the rebound effect (Gómez \& Pérez, 2013; Grafton et al., 2018). Thus, if irrigation modernization continues to lead to the

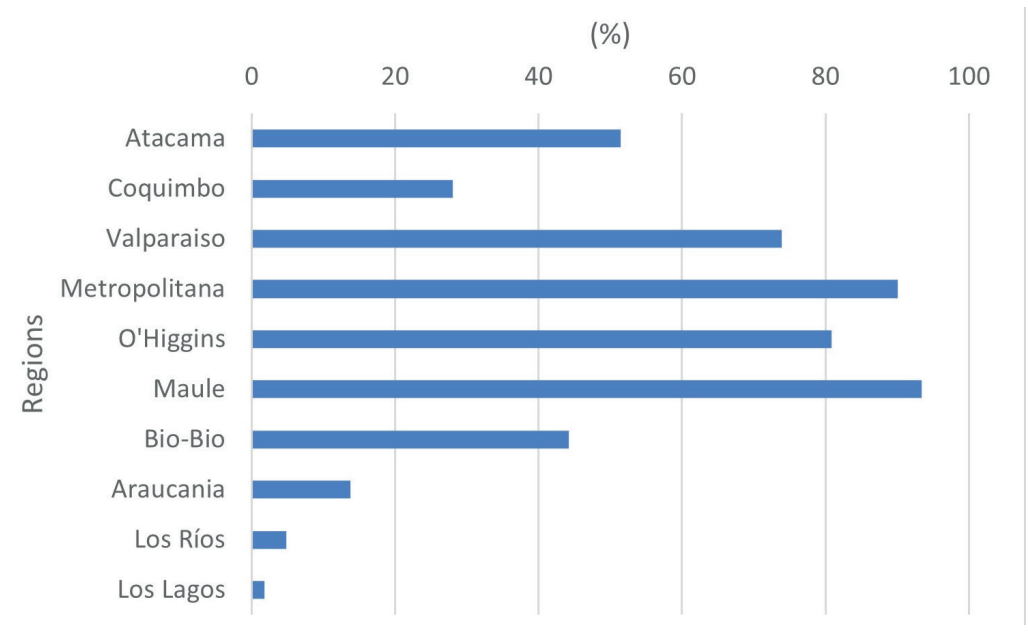

Figure 3. Irrigated area with respect to agricultural area by region.

\footnotetext{
${ }^{3}$ Irrigation efficiency is defined as the relationship between the water stored in the soil depth zone inhabited by crop roots and the water applied by the irrigation system.
} 


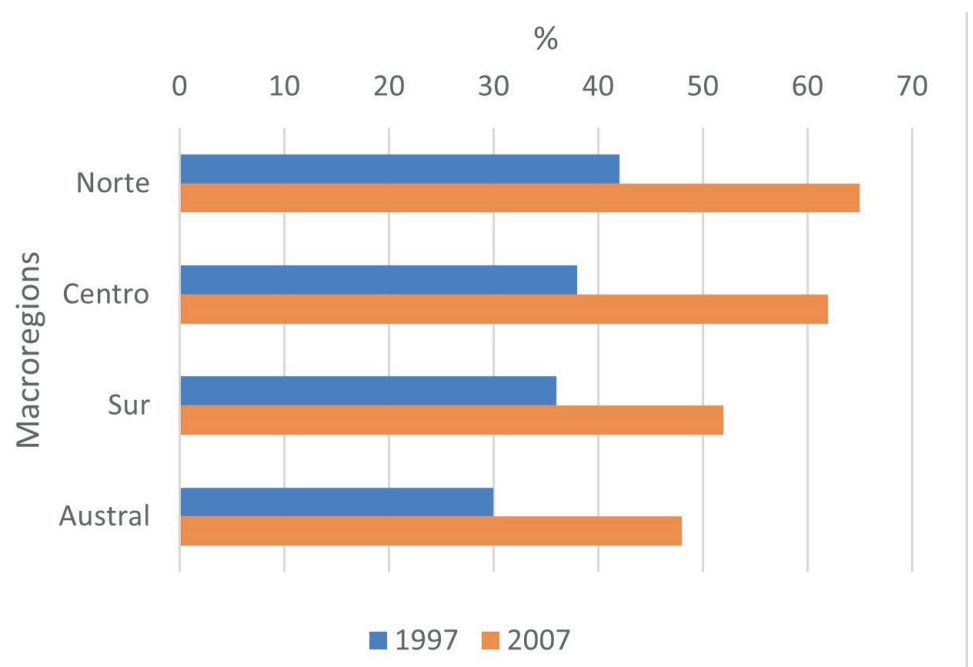

Figure 4. Irrigation efficiency by macrogregion

expansion of irrigated lands, it will not address growing water scarcity challenges. Moreover, Chile's current subsidy program for irrigation water management threatens water resource sustainability (Jordan et al., 2021).

\section{Water Rights: History and its legal nature in Chile}

Chilean legal tradition has always recognized water as a national property for public use, granting, at the same time, rights for the private use of water. The nature of these water rights (WRs) has changed under different water codes.

At present, the public nature of continental waters in natural sources is explicitly formulated in arts. 595 of the Civil Code and 5 of the 1981 Water Code (WC81); and, implicitly, in the Political Constitution (art. 19 No. 24 inc. final, in relation to art. 19 No. 23 Political Constitution) (Vergara \& Rivera, 2018).

Chile's water legislation was designed, in essence, to regulate surface water. WC81 did not give much attention to groundwater management because at the time, groundwater was a marginal water source. Even though special regulations for groundwater management have been issued in recent years, several problems persist (Banco Mundial, 2011; Vergara \& Rivera, 2018; Donoso et al., 2020)

WC81 specifies consumptive WRs for surface and groundwater and nonconsumptive WRs for surface water. Nonconsumptive WRs allow the user to extract water from a river with an obligation of returning it unaltered to its original water source. Consumptive WRs do not require water to be returned once it has been used. In addition, consumptive and nonconsumptive WRs can be permanent or contingent and can be exercised continuously, discontinuously or alternately. Permanent WRs combine volumetric caps per unit time in times of abundance with shares in times of scarcity, which has proven to be appropriate in the case of surface waters (Banco Mundial, 2011). Contingent WRs correspond to water flows that can be used only after permanent WRs have been satisfied. Continuous rights are WRs that allow users to draw water continuously over time. On the other hand, discontinuous rights are those that only allow the use of water in certain periods of time. Finally, alternate rights are those in which the water is distributed between two or more users in succession, a typical case in agricultural communities. 
The requirements for the initial allocation of a WR are established in article 141 of WC81:

1. There must be water available. It is important to note that there is no legal definition of availability that can potentially lead to the exercise of technical or political discretion.

2. The application must:

a) Include the set of requirements established in WC81 and groundwater regulations (Decree 203, 2014).

b) Be published in the Official Gazette, in a Santiago newspaper, and, if the request does not correspond to the Metropolitan region, also in a newspaper of the respective province.

3. Not cause third party effects. It is not legally specified who these third parties are, but in practice, they have been understood as other WR holders. It is the holders of these rights who have the possibility of opposing the request for a new WR that potentially harms them.

If these requirements are met and if there is no competition for the requested WRs, they are granted free of charge. When there are two or more WR applications and insufficient flow to jointly grant the entire requested flow, it is allocated through an auction. However, as Peña-Torres et al. (2019) pointed out, the auction mechanism has not been an effective allocation system.

When resolving a WR request, the General Water Directorate (Dirección General de Aguas, DGA) can accept it, limit the requested flow when there is not sufficient flow, or partially deny it when it is necessary to reserve water for human consumption.

WRs do not have a "use it or lose it" clause. The absence of an obligation to use a WR led to speculation and hoarding. This was particularly evident in the case of nonconsumptive WRs where entry barriers were artificially created for new hydroelectric plants. There is little concern for unused consumptive WRs since, under a proportional use system, all water is ultimately distributed to users (Hearne \& Donoso, 2005) . In fact, Dourojeanni and Jouravlev (1999) estimated that the percentage of consumptive WRs not used was less than one percent of the total consumptive allocated WRs. Notwithstanding, the preoccupation over unused WRs led to a reform of WC81 in 2005, in which the procedure for granting new WRs was modified, and a non-use tariff was introduced. Currently, the amount of water requested must be justified. Due to the difficulties in monitoring the effective use of all WRs, the non-use tariff applies to all consumptive WRs that do not have water collection infrastructure and to all nonconsumptive WRs that do not have collection and restitution infrastructure.

All WRs, as of the entry into force of WC81, are independent and separable from land property rights. Furthermore, they are not sector specific and can be transferred between sectors as well as within economic sectors. This is to facilitate WR markets as a water reallocation mechanism. Therefore, WC81 is an example water regulation based on economic policy instruments, where economic incentives play an important role in water reallocations.

The transfers of WRs between different users are governed by provisions of the Civil Code. In general, the General Water Directorate (DGA) does not have powers regarding the transfers of WRs; only when the transfer requires a change in the water extraction point is authorization of the DGA required to prevent potential damage to third parties and the environment.

\section{Institutional framework for water resources}

Successful water management also depends on effective governance. The WC81 did not establish new institutions; however, it significantly modi- 
fied existing powers established in previous water codes. From the perspective of public institutions, centralized institutions comprise multiple central authorities (ministries, departments, and public agencies) involved in the formulation and regulation of water policies and the judicial system. Currently, the number of actors involved in the formulation of water policies is 43 (World Bank, 2013). However, the main one is the DGA, a technical body of the Ministry of Public Works (MOP).

The DGA has multiple powers and attributions, the most important of which are:

1. Initial surface or groundwater WR allocation.

2. Hydrological planning.

3. Research, measurement, and monitoring of water. Tasks that must include both the quantity and quality of water resources. For this purpose, the DGA maintains and operates the national hydrometric network.

4. Monitor surface and groundwater with powers to prevent, report and sanction any misuse or pollution and to authorize infrastructure investment.

5. Supervise water user organizations.

6. Manage the Public Water Registry (CPA), which is the administrative record in which all information on water resources must be recorded.

WC81 has entrusted decentralized water management to water user organizations (WUAs), private entities integrated by the respective WR holders without any public participation or intervention (Banco Mundial, 2013; DGA, 2017; Vergara \& Rivera, 2018). The characteristic elements of these are the following:

1. Collective water management, in addition to other attributions that the law assigns them.
2. Build, operate, maintain, and improve common hydraulic works that are under its jurisdiction.

3. Monitor and enforce water extraction.

Three types of water user organizations are considered, all of which have a long tradition and history:

1. Water communities (CAs), which act at the level of a common canal. These communities can be organized with respect to surface or groundwater. There are many more surface water communities than groundwater communities.

2. Canal associations (ACs) responsible for infrastructure administration, such as dams, reservoirs, and canal systems. Their number is considerably less than that of water communities.

3. Vigilance boards (JdVs) act at the level of a natural source, bringing together CAs, ACs and some individual holders as their members. They normally manage an entire river, from the source to sea, except in cases where river sectorization operates. JdVs are responsible for the joint management and administration of surface water and groundwater. However, its actions have focused on surface waters, and its activity with respect to groundwater is still developing.

\section{Regulatory and institutional framework for irrigation}

The main public institution for water in agriculture is the National Irrigation Commission (CNR), an agency of the Ministry of Agriculture (MINAGRI) that was created in 1975 to coordinate efforts and supervise investments in this area. Additionally, in 1985, it was entrusted with the administration of Law 18,450 for the Promotion of Private Investment in Irrigation and Drainage Infrastructure 
(minor irrigation and drainage projects). The main functions of CNR include:

1. Contribute to the formulation of national irrigation policy;

2. Improve irrigation efficiency;

3. Focus efforts on the development of extreme regions of the country and groups of producers in vulnerable situations;

4. Promote private investment in irrigation technologies and infrastructure in irrigation and drainage; and

5. Assess the technical and economic feasibility of investments in irrigation infrastructure in the country's hydrographic basins.

The CNR follows the guidelines established by the Council of Ministers of the CNR, chaired by the Minister of Agriculture and integrated by the Ministers of Finance, Public Works, Social Development and Economy, Development and Reconstruction. Other MINAGRI institutions involved in the irrigation sector are as follows:

1. National Institute for Agricultural Development (INDAP), which promotes irrigation among small farmers.

2. Agricultural Research Institute (INIA), through research and technology transfer.

3. Agricultural and Livestock Service (SAG) develops actions to preserve and improve renewable natural resources that affect agricultural, livestock and forestry production by preventing contamination of irrigation water.

In turn, the MOP participates in the subsector through the actions of the Directorate of Hydraulic Works (DOH) and the Department of Concessions Coordination (CGC). DOH is tasked with designing, constructing, maintaining, repairing, and operating large irrigation infrastructure built with public funds. The mission of the CGC is to create water use infrastructure for national development, strengthening publicprivate partnerships.

The development of irrigation in Chile is framed within the following regulatory framework (Martin \& Saavedra, 2018):

1. Water Code of 1981,

2. Environment Law (Law 19,300) and its regulations,

3. DFL 1.123, on the investment of irrigation infrastructure by the state,

4. D.S. MOP 900 (Concessions Law),

5. Law 18,450 , for the promotion of private investment in irrigation and drainage.

In what follows, we describe Law 18,450 in force since 1985, which consists of an incentive for private investment in irrigation and drainage projects both for community infrastructure (water distribution canals and drainage) and for on-farm investments in irrigation technologies. The objective of this law is that farmers and WUAs, with an emphasis on small and medium farmers, increase their irrigated area and improve irrigation efficiency.

This is a tool to promote private investment in irrigation and drainage works based on demand and whose operation only triggers fiscal outlay once the work is performed. Its purpose is to increase irrigated surfaces, improve inadequate irrigation management, promote irrigation efficiency, and reduce drainage problems.

The program assigns subsidies for projects through CNR contests. The maximum bonus ranges from $70 \%$ for large projects ( $>40 \mathrm{ha}$ ) and $90 \%$ for small farmers. Bonus certificates are given to the projects 
that are awarded the tenders. These certificates can only be cashed at the General Treasury of the Republic once the investment has been implemented and satisfactorily certified. Normally, two to three years elapse between the delivery of the certificates to the beneficiaries and actual payment. A proportion of the approved projects are not implemented due to capital restrictions, particularly in the case of small farmers.

In 2013, Law $\mathrm{N}^{\circ} 18,450$ was modified to incentivize integral and multiple-use large irrigation and drainage infrastructure, the cost of which exceeds $30,000 \mathrm{UF}^{1}$ with a maximum ceiling of 250,000 UF. A detailed explanation of how this program works can be found in Donoso (2017) and Martin and Saavedra (2018).

The law's assessment and evaluation show good results and economic impacts of the increased efficiency in the irrigated surface (Dipres, 2006; Martin \& Saavedra, 2018; Jordan et al., 2021). The program has contributed to a significant increase in the country's newly irrigated area, as well as the surface with efficient irrigation systems. In the last decade, its application has targeted small and medium-sized producers, fulfilling the objective of the Ministry of Agriculture to prioritize these sectors through sectoral public policies.

Law 18,450 expires in December 2021, and an extension of the law for 15 years is currently being discussed. Relevant modifications from a sustainability point of view are being considered. The following stand out:

1. Incorporate a new conceptual approach called "saving water". A new weighting factor would be included for projects that conserve or save water for other uses, thus preventing the rebound effect.
2. In areas of water scarcity, subsidies are limited to projects that incorporate new irrigation surfaces.

\section{Performance and Challenges of Water Resource Management in Agriculture}

Notwithstanding the advances and positive aspects of the legal and institutional framework, the fragmentation of powers and functions between different public and private entities and the lack of coordination between them have prevented an effective, transparent and secure institutional framework (Banco Mundial, 2013; Donoso et al., 2021).

Currently, the registry of water resource information presents significant data limitations. The DGA's public database does not contain precise information on the extraction and actual use of water resources. These problems affect the definition of water availability and have led to an overallocation that has intensified conflicts over water. The DGA is carrying out an update of the Chilean Water Balance to overcome some of the deficient estimates of the water balance (Donoso et al., 2021).

WR information is dispersed among different organizations; therefore, a considerable number of WRs have not been registered in the DGA Public Water Registry. On the other hand, not all WRs granted previously to WC81 are registered or listed in any registry. Therefore, the number of WRs that are recorded is markedly lower than that of actual WRs. Therefore, Chile's registry of information on water resources and WRs is neither complete nor reliable.

The state has supported investment in irrigation infrastructure under the Build, Operate and Transfer (BOT) model. However, the capacity

\footnotetext{
${ }^{4}$ The UF is an inflation-indexed unit published by the Central Bank of Chile. The value of the UF in March of 2021 was 1 UF $=\$ 41.18$ USD.
} 
for hydrological regulation is limited (Banco Mundial, 2011). Therefore, investments associated with the accumulation of water are required (DGA, 2016), such as large reservoirs, dams and aquifer infiltration systems.

In Chile, WUAs have existed in Chilean surface water resource management since colonial times. However, groundwater has traditionally been managed in an individualistic way, leading to overextraction and significant reductions in water levels. In fact, there are few groundwater communities (CASs) in Chile. Although WC81 establishes that a CAS must be established when the aquifer is declared under restriction or prohibition, to date, only 13 CASs have been legally constituted, even though in Chile, 159 aquifers have been declared under restriction and prohibition. This has contributed to a conflict between water for agriculture and human consumption in aquifers with significant decreases in the available volume, such as in La Ligua and Petorca (Donoso et al., 2020).

The DGA (2017) noted that many WUAs are professionally managed. However, a significant proportion of these have not updated their capacity to face the current challenges of water management (DGA, 2017). Due to these deficiencies, the DGA and CNR have implemented programs to strengthen WUAs. Therefore, in general terms, WUAs do not fully satisfy Ostrom's 8 principles for effective collective water management, which explains their limited management capacity.

In addition, WUAs have a responsibility to monitor and enforce water extraction. However, only a small number have complied with this obligation (DGA, 2017). Taking this into account, a WC81 reform (approved in 2018) established new legal powers for the DGA to strengthen its inspection and sanction capacities. However, this has been deficient because the DGA was not provided with the necessary resources (human, technical and financial) to effectively control and monitor all extractions (Donoso et al., 2021).
Growing water scarcity has activated WR markets in Chile. Although the reallocation of WRs through the WR market has not been common in most of Chile, the existence of consumptive WR markets has been documented. Hearne (2018) noted that there has been an active market for WRs in basins where water is scarce and has a high economic value.

The presence of flexible gates in the distribution infrastructure, as well as well-managed WUAs, has reduced transaction costs and encouraged WR transactions. In basins with rigid water distribution infrastructure, the WR market has not been active due to the high costs of modifying this infrastructure.

The majority of WR transactions have been between agricultural users. In general, intersectoral water transfers have not been frequent (Donoso et al., 2014; Hearne \& Donoso, 2014). Even in the active markets of the Limarí Basin, only $2 \%$ of transactions between 2000 and 2016 transferred water away from agriculture (Hearne, 2018). In the Copiapó Basin, where mining and high-value agriculture have competed for increasingly scarce water, WR markets have been active among farmers, with prices rising with increasing scarcity (Donoso et al., 2014). Many WR transactions have been for relatively small amounts of water and for low values. This indicates that transaction costs have often not been prohibitive (Hearne, 2018).

The WC81 allows permanent and temporary exchanges to take place. However, active temporary exchanges are only present in basins with flexible water distribution infrastructure.

WR prices have been very variable. This great price dispersion is due to the lack of reliable public information on WR prices and transactions (Donoso, 2015). Given this, each WR transaction is the result of a bilateral negotiation between an interested buyer and a WR seller in which the information, market experience and negotiation 
capacity of each agent is important in determining the final value (Donoso, et al., 2014).

The transfer of WRs has produced important economic benefits for both buyers and sellers, particularly in basins located in the northern and central macroregions, characterized by greater water scarcity (Hearne \& Donoso, 2014; Hearne, 2018). These economic benefits drive cross-sector transactions and WR exchanges between farmers.

However, WR markets have not been accepted by all agents. Several farmers have argued that land and water should not be separated (Donoso et al., 2010). This has prevented many farmers from offering WRs without also selling their land. Furthermore, it does not have full political acceptability. For example, some members of Congress proposed a reform of the water code that states that water management based on productive and market logic is dysfunctional in regard to the protection, rational use and equitable distribution of water resources.

Several Chilean basins are characterized by return flows, which implies that water flows are used consecutively by different users throughout the basin. Peña (2018) noted, for example, that water in the Coquimbo region is used between 2 and 4 times consecutively. In the northern macroregion, this implies that $88 \%$ of the effective runoff is used before it reaches the sea (Peña, 2016).

This has generated externalities since the hydrographic basins located in the northern and central macroregions have historically been managed by sections, considering that these basins are independent of each other. In this system, WRs have been granted for each section, with no obligation to conserve flows for downstream sections. Therefore, any change in the efficiency of water use due to the adoption of efficient irrigation technologies or transfers of WRs to more intensive water users implies reductions in water flows in downstream sections. This externality is not contemplated in the current legal regulations.
Groundwater use has increased at an exponential rate in recent decades, and at present, many important aquifers are under considerable stress, as withdrawals, predominantly for agricultural use, outpace recharge. This is due to the overallocation of WRs, which is explained, in part, by an allocation based on a predictable use factor. Before 2000, the DGA evaluated the available flow that could be allocated based on an estimate of its intended use. For example, WRs for agriculture were assumed to represent $20 \%$ of the total requested use. The theoretical use factor for drinking water and the mining industry was $75 \%$.

The problem is that the granted groundwater rights do not establish this foreseeable use and therefore allow the extraction of $31,500 \mathrm{~m}^{3} /$ year. Therefore, if a WR is transferred from agriculture to mining or drinking water operators, the volume of groundwater drawn increases significantly. For example, Rinaudo \& Donoso (2019) estimated that the volume extracted increased by $76 \%$ in the Copiapó aquifer due to increases in irrigation efficiency that translated into an increase in irrigated area and transfers of WRs to more intensive users.

The average efficiency of irrigation in Chile is $57 \%$. This is the result of an increase of $85.1 \%$ and $298.2 \%$ in areas with sprinkler irrigation and microirrigation, respectively, driven largely by Law 18,450 . Evidence indicates that the application of this law has been a dynamic element in Chilean agriculture and has had wide acceptance and demand by producers of various property sizes (Dipres, 2006).

However, agriculture presents an economic water productivity of $\$ 0.52 / \mathrm{m}^{3}$ (Donoso, 2021), which is lower than the sector's average economic water productivity in Latin America and the Caribbean, which is $\$ 1.01 / \mathrm{m}^{3}$ (World Bank, 2019; Mekonnen and Hoekstra, 2011). Molinos-Senante et al. (2016) found that the average economic water productivity for farmers in the Limarí Basin was low, even when the average irrigation 
efficiency was $95 \%$. This finding implies that there is a considerable possibility of reducing water consumption in the Limarí Basin without affecting production levels.

Chile's institutional and legal framework for water management and agricultural water management have fallen short of what is needed to address the issues that Chile faces. Improving the performance of agricultural water management in Chile requires strengthening of horizontal and vertical inter-institutional coordination as well as institutions themselves. The inability to management the entire river basin and involve multiple stakeholders and sectors has led to increased conflicts, inefficiencies, and challenges for agricultural water management. Thus, adopting an integrated water resources management approach is a priority so that Chile can face its current and future water management challenges.

\title{
Resumen
}

\begin{abstract}
G. Donoso. 2021. Gestión de los recursos hídricos en la agricultura de Chile y sus desafíos. Int. J. Agric. Nat. Resour. 171-185. El agua siempre ha sido un recurso estratégico para el desarrollo económico, particularmente en las regiones áridas y semiáridas del norte de Chile. Actualmente, la producción de la superficie bajo riego aporta entre un 60 a $65 \%$ del PIB del sector agrícola nacional y contribuye en más del $80 \%$ a las exportaciones de origen agrícola del país. Cabe destacar que el sector agrícola es el principal sector económico en términos de utilización del recurso hídrico, consumiendo un $82 \%$ del total del agua que se dispone a nivel nacional. En la actualidad, existe un déficit de agua superficial que cubre la demanda de riego en las regiones central y norte. Se proyecta que este déficit aumentará como resultado del cambio climático, lo que aumentaría los desafíos para satisfacer las necesidades de agua para la agricultura. El objetivo de este artículo es revisar de manera integral los aspectos clave de las políticas de manejo del agua y del agua para la agricultura chilena, considerando sus interfases, brindando al lector una visión general de las principales características de este modelo, una evaluación de su efectividad y los principales desafíos agrícolas.
\end{abstract}

Palabras Clave: Chile, gestión del agua, gestión del agua en la agricultura, gobernanza del agua, mercados de derechos de agua, política del agua.

\section{References}

Banco Mundial. (2013). Estudio para el mejoramiento del marco institucional para la gestión del agua. Dirección General de Aguas, Ministerio de Obras Públicas de Chile. http://reformacodigodeaguas.carey.cl/wp-content/uploads/2014/09/ Informe-Banco-Mundial-Estudio-para-el-mejoramiento-del-marco-institucional.pdf

Bauer, C.J. (1997). Bringing water markets down to earth: The political economy of water rights in
Chile, 1976-1995. World development, 25(5), 639-656.

Bauer, C.J. (2004). Results of Chilean water markets: Empirical research since 1990. Water Resources Research, 40(9).

Bauer, C.J. (2010). Siren song: Chilean water law as a model for international reform. Routledge.

Bauer, C.J. (2012). The experience of water markets and the market model in Chile. In Water Trading and Global Water Scarcity (pp. 150-163). Routledge. 
Budds, J. (2004). Power, nature and neoliberalism: the political ecology of water in Chile. Singapore Journal of Tropical Geography, 25(3), 322-342.

Budds, J. (2009). The 1981 water code: The impacts of private tradable water rights on peasant and indigenous communities in Northern Chile. In: Alexander, William L. ed. Lost in the long transition: Struggles for social justice in neoliberal Chile. Lanham: Lexington Books.

Budds, J. (2018). Securing the market: Water security and the internal contradictions of Chile's Water Code. Geoforum (January), 1-11.

DGA. (2016). Atlas del Agua. Dirección General de Agua, Ministerio de Obras Públicas. www.dga.cl

DGA. (2017). Diagnóstico Nacional de Organizaciones De Usuarios. http://bibliotecadigital.ciren.cl/ handle/123456789/33000.

Dipres. (2006). Informe Final De Evaluación Programa De Bonificación Por Inversiones De Riego Y Drenaje Ley N ${ }^{\circ} 18.450$ Ministerio De Agricultura Comisión Nacional De Riego (CNR).

Donoso, G. (2015). Chilean water rights markets as a water allocation mechanism. In M. Lago, J. Mysiak, C. M. Gómez, G. Delacámara, \& A. Maziotis (Eds.), Use of Economic Instruments in Water Policy: Insights from International Experience (Issue 14, p. 423). Springer International Publishing. https://doi.org/10.1007/978-3-31918287-2

Donoso, G. (2017). Logros y Perspectivas del Régimen de Fomento a la Eficiencia Hídrica en la Agricultura Chilena. In Agua y Sociedad (pp. 433-456). Lajouane15.

Donoso, G. (Ed.). (2018). Water policy in Chile (Vol. 21). New York: Springer

Donoso, G. (2021). Economics of Water Resources. In Fernandez, B. and Gironas, J. (eds). Water Resources of Chile Springer Nature Switzerland 10.1007/978-3-030-56901-3 18

Donoso, G., Blanco, E., Franco, G., \& Lira, J. (2012). Seguridad hídrica y alimentaria en América Latina y España: el caso de Chile.

Donoso, G., Cancino, J., Melo, O., Rodríguez, C., \& Contreras, H. (2010). Análisis del Mercado del Agua de Riego en Chile: Una Revisión Crítica a través del caso de la Región de Val- paraíso. ODEPA, Ministerio de Agricultura de Chile. http://www.odepa.cl/wp-content/files mf/1369772320Analisis_agua_riego_Valparaiso.pdf

Donoso, G., Melo, O., \& Jordán, C. (2014). Estimating Water Rights Demand and Supply: Are Non-market Factors Important? Water Resource Management, 28(12), 4201-4218. https://doi. org/10.1007/s11269-014-0739-3

Donoso, G., Lictevout, E., \& Rinaudo, J.D. (2020). Groundwater Management Lessons from Chile. In Global Issues in Water Policy (Vol. 24, pp. 481-509). Springer. https://doi.org/10.1007/9783-030-32766-8_25

Donoso, G., Barria, P., Chadwick, C., \& Rivera, D. (2021) Assessment of Water Markets in Chile. Capitulo 12. En Wheeler, S. (ed.) Water Markets: A Global Assessment. Edward Elgar. 9781 788976923

Dourojeanni, A., \& Jouravlev, A. (1999). El Código De Aguas De Chile: Entre La Ideología Y La Realidad. In Serie Recursos Naturales e Infraestructura $N^{\circ}$. 3. CEPAL.

Gómez, C.M., \& Pérez, C.D. (2013). Myths and Maths of Water Efficiency: An Analytical Framework to Assess the Real Outcome of Water Saving Technologies in Irrigation. In 87th Annual Conference of the Agricultural Economics Society. http://ageconsearch.umn.edu/ bitstream/158690/2/Carlos Mario Gómez Gómez_AES13_finalversion.pdf

Grafton, R.Q., Williams, J., Perry, C.J., Molle, F., Ringler, C., Steduto, P., Udall, B., Wheeler, S.A., Wang, Y., Garrick, D., \& Allen, R.G. (2018). The paradox of irrigation efficiency. Science, 361(6404), 748-750. https://doi.org/10.1126/science.aat9314

Grafton, R.Q., Libecap, G., McGlennon, S., Landry, C., \& O'Brien, B. (2011). An integrated assessment of water markets: A cross - country comparison. Review of Environmental Economics and Policy, 5 (2), 219-239. https://doi.org/10.1093/ reep/rer002

Hadjigeorgalis, E. (2009). A place for water markets: performance and challenges. Applied Economic Perspectives and Policy, 31(1), 50-67. 
Hearne, R.R. (2007). Water markets as a mechanism for intersectoral water transfers: the Elqui Basin in Chile. Paddy and Water Environment, 5(4), 223-227.

Hearne, R. (2018). Water Markets. In G. Donoso (Ed.), Water Policy in Chile (pp. 117-130). Springer International Publishing. https://doi. org/10.1007\%2F978-3-319-76702-4

Hearne, R., \& Donoso, G. (2014). Water Markets in Chile: Are they meeting needs?. In Water markets for the 21st century (pp. 103-126). Springer, Dordrecht.

Hearne, R., \& Donoso, G. (2005). Water institutional reforms in Chile. Water Policy 7, pp. 53-69. http://www.iwaponline.com/wp/00701/ wp007010053.htm

Hearne, R., \& Donoso, G. (2014). Water Markets in Chile: Are They Meeting Needs? In W. Easter \& Q. Huang (Eds.), Water Mrkets for the 21st Century: What have we Learnt? (Global Issues in Water Policy 11). Springer-Verlag. https://doi. org/10.1007/978-94-017-9081-9_6

Hurlbert, M.A., \& Diaz, H. (2013). Water governance in Chile and Canada: a comparison of adaptive characteristics. Ecology and Society, 18(4).

INE. (1997). Censo Agropecuario 1997. http://www.ine. cl/canales/chile_estadistico/censos_agropecuarios/ pdf/300311/VIcensonacionalagropecuario1997.pdf

INE. (2007). Censo Agropecuario 2007. Instituto Nacional de Estadistica. http://www.ine.cl/canales/chile_estadistico/censos_agropecuarios/ censo_agropecuario_07.php.

Jordan, C., Donoso, G., \& Speelman, S. (2021). Irrigation subsidy policy in Chile: lessons from the allocation, uneven distribution and water resources implications. International Journal of Water Resources Development, 1-22. https://doi. org/10.1080/07900627.2021.1965964

McPhee, J. (2018). Hydrological setting. In Water policy in Chile (pp. 13-23). Springer, Cham.

Martin, F., \& Saavedra, F. (2018). Irrigated Agriculture. In G. Donoso (Ed.), Water Policy in Chile (pp. 165-177). Springer International. https:// doi.org/10.1007/978-3-319-76702-4

Molinos-Senante, M., Donoso, G., \& Sala-Garrido, R. (2016). Are participants in markets for wa- ter rights more efficient in the use of water than non-participants? A case study for Limarí Valley (Chile). Environ Sci Pollut Res Int, 1-14. https:// doi.org/10.1007/s11356-016-6187-2

ODEPA. (2010). Estimación del Impacto Socioeconómico del Cambio Climático en el Sector Silvoagropecuario de Chile. https:/www.odepa. gob.cl/wp-content/uploads/2010/01/ImpactoCambioClimatico.pdf

ODEPA. (2012). Cambios Territoriales y Tecnológicos en el Riego Agrícola en Chile entre los Años 1997 y 2007. https://www.odepa.gob.cl/publicaciones/articulos/cambios-territoriales-y-tecnologicos-en-el-riego-agricola-en-chile-entre-losanos-1997-y-2007-2

ODEPA. (2017). Agricultura Chilena: Reflexiones y Desafios al 2030. https://www.odepa.gob.cl/wpcontent/uploads/2018/01/ReflexDesaf_2030-1.pdf

Palerm-Viqueira, J. (2010). A comparative history, from the 16th to 20th centuries, of irrigation water management in Spain, Mexico, Chile, Mendoza (Argentina) and Peru. Water policy, 12(6), 779-797.

Peña-Torres, J., Vargas, E., \& Donoso, G. (2019). Remate de Derechos de Agua en Chile: ¿Que paso Pos-Reforma del Código de Aguas de 2005? Estudios Públicos, 155(Invierno), 59-103. https:// www.cepchile.cl/cep/estudios-publicos/n-151-ala-180/estudios-publicos-n-155/remate-dederechos-de-agua-en-chile-que-paso-posreforma-del-codigo-de

Peña, H. (2018). Integrated Water Resources Management in Chile: Advances and Challenge. In G. Donoso (Ed.), Water Policy in Chile (pp. 197208). Springer International Publishing. https:// doi.org/10.1007\%2F978-3-319-76702-4

Peña, Humberto. (2016). A Desafios de la seguridad hídrica en América Latina y el Caribe. https:// repositorio.cepal.org/handle/11362/40074

Prieto, M., Fragkou, M.C., \& Calderón, M. (2020). Water policy and management in Chile. Encyclopedia of water: science, technology, and society. Wiley-Blackwell, Hoboken, 2-58

Rinaudo, J.-D., \& Donoso, G. (2019). State, market or community failure? Untangling the determinants of groundwater depletion in Copiapó (Chile). International Journal of Water Resourc- 
es Development, 35(2), 283-304. https://doi.org/ $10.1080 / 07900627.2017 .1417116$

Sandoval Jeria, J. (2003). El riego en Chile. Dirección de Obras Hidráulicas, Ministerio de Obras Públicas, Chile. http:// bibliotecadigital.ciren.cl/bitstream/handle/123456789/29015/El\%20riego\%20en\%20 Chile.pdf? sequence $=1 \&$ isAllowed $=\mathrm{y}$
Vergara, A., \& Rivera, D. (2018). Legal and Institutional Framework of Water Resources. In G. Donoso (Ed.), Water Policy in Chile (Vol. 21, pp. 67-85). Springer International Publishing. https://doi.org/10.1007/978-3-319-76702-4_5

World Resources Institute. (2021). Water Stress by Country. https://www.wri.org/resources/chartsgraphs/water-stress-country 